\title{
Karakteristik Fenotipik dan Pengelompokan Jagung Pulut Hibrida Zea mays L. Hasil Persilangan Puncak
}

\author{
Juhriah $^{1}$, Muhammad Azrai ${ }^{2}$, Elis Tambaru ${ }^{1}$, Jum Eka Rahayu ${ }^{1}$ \\ ${ }^{I}$ Departemen Biologi, Fakultas Matematika dan Ilmu Pengetahuan Alam \\ Universitas Hasanuddin \\ ${ }^{2}$ Balai Penelitian Tanaman Serealia, Maros, Sulawesi Selatan \\ E-mail: ekarahayu.er48@gmail.com
}

\begin{abstract}
This research is the phenotypic characteristics and grouping of hybrid waxy corn Zea mays L. product of the top cross had been carried out in the experimental plant Indonesian Cereals Research Institute (ICERI) in Maros South Sulawesi. This research aims to determine the phenotypic characters of the hybrid of waxy corn Zea mays L. product of the top cross and grouping based on its phenotypic characteristics. This research used a randomized block design (RBD) with $17^{\text {th }}$ treatments (corn strains) and three replications. Waxy corn strains used were: URI 1 (G8), G8G1, G8G2, G8G3, G8G4, G8G5, G8G6, G8G7, Soppeng (G10), G10G1, G10G2, G10G3, G10G4, G10G5, G10G6, G10G7, and Paramitha.. All data (qualitative and quantitative) are arranged in binary tables and grouped using the NTSYST program. The observations show that the data obtained comes from 14 quantitative characters and 17 qualitative characters. Quantitative data from 14 characters were tested and the results of 10 characters were significantly different and the other 4 were not significantly different. The grouping results show that the 17 corn strains studied formed 3 groups at the similarity coefficient of 0.76 . Soppeng's corn is different from the others.
\end{abstract}

Kata kunci: Waxy corn, top cross, hybrid, phenotypic

\section{PENDAHULUAN}

Jagung Zea mays L. adalah tanaman semusim yang termasuk dalam golongan spermatophyta. Jagung merupakan makanan pokok kedua di Indonesia setelah beras. Selain sebagai bahan makanan pokok, jagung juga digunakan sebagai bahan makanan ternak dan bahan baku industri misalnya industri tepung. Pada tahun 2020, permintaan jagung di negara sedang berkembang diperkirakan akan melebihi permintaan beras dan gandum. Permintaan jagung dunia diperkirakan akan meningkat sebesar 50\%, yakni dari 558 juta ton pada tahun 1995 menjadi 837 juta ton pada tahun 2020 (Zubachtirodin et al. 2011).

Tanaman jagung tumbuh baik pada daerah dataran rendah hingga dataran tinggi pada ketinggian sekitar 2200 mdpl, membutuhkan curah hujan sekitar 600-1200 mm pertahun dengan temperatur ratarata $14-30{ }^{\circ} \mathrm{C}$. Jenis tanah yang sesuai untuk jagung adalah tanah alluvial atau tanah lempung yang subur dan bebas dari genangan air (Kartasapoetra, 1988). 
Saat ini para petani masih banyak menggunakan benih lokal dalam membudidayakan jagung, terutama jagung pulut karena industri baik jagung pulut masih kurang. Jagung pulut atau biasa dikenal dengan jagung ketan merupakan jagung yang mempunyai karakteristik seperti ketan yang lengket dengan citarasa enak, lebih gurih, pulen dan lembut. Jagung ini pertama kali ditemukan di China pada tahun 1909 yang menunjukkan adanya pe rbedaan dari jenis lainnya dikarenakan adanya gen tertentu yang mengatur karakter jagung tersebut. Berdasarkan hasil penelitian bahwa jagung pulut memiliki kandungan pati hampir 100\% berupa amilopeptin (Subekti et al. 2008).

Jagung pulut memiliki citarasa yang enak, namun produktivitas masih sangat rendah. Oleh karena itu, perlu dilakukan hibridisasi untuk menghasilkan jagung pulut baru, sehingga meningkatkan produksinya. Hibrida merupakan cara produksi jagung di berbagai Negara seperti di Amerika Serikat, negara perintis jagung hibrida, serta India, Muangthai dan Taiwan. Semula penanaman hibrida secara besar-besaran di Negara tersebut dianggap tidak praktis, banyak factor yang sudah klasik yang selalu dikemukakan dapat menghambat perluasannya. Teknik produksi benih hibrida berbeda dengan teknik produksi benih varietas bersari bebas, setiap kali harus membuat persilangan antara kedua induknya, dan mempergunakan biji generasi pertama (FI) sebagai benih. Umumnya produksi benih paling efisien untuk hibrida-hibrida silang tiga, silang ganda, dan silang puncak ganda, asalkan silang tunggal induk dipakai sebagai induk betina. Penanaman hibrida mungkin dapat menunjang program pemerintah meningkatkan dan menganekaragamakan ekspor nonmigas (Moentono, 2001).

Analisis dendrogram (pengelompokkan) dimaksudkan untuk menilai kemiripan antar koleksi kultivar tanaman jagung dengan metode analisis dendrogram. Data-data morfologi dikumpulkan dari sejumlah kultivar, ditransformasikan menjadi data biner dalam bentuk matriks. Dari matriks data biner ini, selanjutnya dihitung matriks kemiripan antar nomor koleksi tanaman jagung yang diamati. Pengelompokan ini menggambarkan hubungan kemiripan antara individu tanaman koleksi yang diamati berdasarkan morfologi. Untuk menyimpulkan kekerabatan antara jenis yang diamati, semua data yang terkumpul dianalisis dengan menghitung jarak Euclid yang dipertautkan berdasarkan kekerabatan terdekat. Analisis cluster akan menghasilkan dendrogram yang digunakan menilai pola keragaman (Boik, 2004).

Karakter dari hasil hibridisasi perlu untuk diketahui fenotipnya antara yang satu dengan yang lain apakah berbeda atau tetap sama. Karakterisasi ini perlu dilakukan pada setiap genotipe, sehingga memudahkan untuk pengawasan mutu genetik dan varietas.

\section{METODE PENELITIAN}

\section{Alat dan Bahan}

Alat-alat yang digunakan dalam penelitian ini adalah cangkul, tali plastik, tugal, mistar, bambu, caliper digital, timbangan, gunting, meteran, kamera, label, dan alat tulis. Bahan-bahan yang digunakan dalam penelitian ini adalah 17 galur benih jagung pulut hibrida yang diperoleh dari persilangan puncak atau Top Cross yaitu URI 1 (G8), G8G1, G8G2, G8G3, G8G4, G8G5, G8G6, G8G7, Soppeng (G10), G10G1, G10G2, G10G3, G10G4, G10G5, G10G6, G10G7, dan Paramitha, pupuk urea, pupuk NPK, fungisida, herbisida, dan insektisida. 


\section{Prosedur Kerja}

Metode yang digunakan adalah Rancangan Acak Kelompok (RAK) yaitu 14 perlakuan (galur) dengan 3 (tiga) ulangan. Mula-mula dilakukan persiapan lahan dengan membuat petak-petak untuk tempat penanaman serta pembuatan lubang. Ukuran petak penanaman adalah $40 \mathrm{~cm}$ x $4 \mathrm{~m}$, jarak antara baris $40 \mathrm{~cm}$ dan terdapat 2 baris setiap nomor plot dengan setiap baris terdapat 20 lubang.

Pemberian fungisida berbahan aktif metalaxil diberikan pada benih hibrida silang puncak sebelum tanam untuk mencegah penyakit bulai. Pada setiap lubang tanam juga diberi insektisida carbofuran berbahan aktif untuk mencegah kerusakan benih oleh semut dan lalat bibit. Penanaman dilakukan pada lubang tanam yang ditugal dengan jarak tanam $80 \mathrm{~cm}$ x $20 \mathrm{~cm}$, ditanam I biji / lubang tanam. Pemupukan pertama umur 11 hari dengan dosis $200 \mathrm{~kg}$ pupuk phonska dan $100 \mathrm{~kg}$ pupuk urea. Pemupukan susulan pada umur 35 hst (hari setelah tanam) dengan dosis $100 \mathrm{~kg}$ phonska dan 200 kg urea. Sebelum pemupukan pertama terlebih dahulu disemprotkan Herbisida Calaris untuk mengendalikan gulma.

Setelah itu dilakukan pengendalian hama dan penyakit yang dapat merusak tanaman jagung tersebut. Sekitar \pm 90 hari setelah masa penanaman dapat dilakukan panen dimana biji sudah tua. Diberi label pada kantong kertas untuk tempat biji yang sudah kering kemudian setiap kantong berisi biji dari masing-masing tongkol yang berbeda-beda.

\section{Parameter Pengamatan Fenotipe}

Tabel 1. Pengamatan Karakteristik Tanaman Jagung

\begin{tabular}{|c|c|c|}
\hline No. & Organ Tanaman & Parameter Pengamatan \\
\hline 1. & Daun Pertama & - Warna antosianin dan bentuk ujung daun \\
\hline 2. & Daun & $\begin{array}{l}\text { - Sudut diantara helai dan batang (pada daun di atas tongkol teratas), } \\
\text { pola helai daun, dan lebar helai daun (pada daun tongkol teratas) }\end{array}$ \\
\hline 3. & Akar & - $\quad$ Pewarna antosianin pada akar tunjang \\
\hline 4. & Batang & $\begin{array}{l}\text { - Warna antosianin (pada pertengahan tinggi tanaman), tinggi } \\
\text { tanaman }\end{array}$ \\
\hline \multirow[t]{6}{*}{5.} & \multirow[t]{6}{*}{ Malai } & - Umur antesis \\
\hline & & $\begin{array}{l}\text { Warna antosianin pada dasar kelopak (pada tengah pertiga poros } \\
\text { utama), warna antosianin tidak termasuk dasar kelopak, dan pada } \\
\text { kepala sari yang masih segar }\end{array}$ \\
\hline & & - $\quad$ Kerapatan bulir \\
\hline & & $\begin{array}{l}\text { Sudut diantara poros utama dan cabang samping (pada malai } \\
\text { bagian pertiga bawah) }\end{array}$ \\
\hline & & $\begin{array}{l}\text { - Letak percabangan samping, panjang cabang samping, dan jumlah } \\
\text { cabang samping utama. }\end{array}$ \\
\hline & & $\begin{array}{l}\text { - Panjang poros utama di atas cabang samping terbawah, dan bagian } \\
\text { lebih atas }\end{array}$ \\
\hline \multirow[t]{4}{*}{6.} & \multirow[t]{4}{*}{ Tongkol } & - Umur munculnya rambut \\
\hline & & $\begin{array}{l}\text { - Warna antosianin pada rambut, dan intensitas warna antosianin } \\
\text { rambut }\end{array}$ \\
\hline & & - $\quad$ Panjang tangkai, dan panjang (tanpa kelobot) \\
\hline & & - Diameter (di tengah-tengah) \\
\hline
\end{tabular}


Juhriah dkk/Jurnal Ilmu Alam dan Lingkungan 10 (1) (2019) 51 - 60

\begin{tabular}{|l|l|ll|}
\hline No. & Organ Tanaman & \multicolumn{1}{c|}{ Parameter Pengamatan } \\
\hline \multirow{4}{*}{} & \multirow{2}{*}{$*$} & - & Bentuk tongkol \\
\cline { 3 - 4 } & & - & Antosianin dan intensitas warna antosianin pada kelopak janggel \\
\hline 7. & \multirow{2}{*}{ Biji } & - & Jumlah baris biji pada tongkol \\
\cline { 3 - 4 } & & - & Tipe biji (pada tengah pertiga tongkol) \\
\cline { 3 - 4 } & & - & Warna utama permukaan biji \\
\hline
\end{tabular}

\section{Analisis Data}

Semua data (kualitatif dan kuantitatif) disusun dalam tabel biner dan dilakukan pengelompokan menggunakan progran NTSYST (Numerical Taxonomy System). Hasil yang diperoleh berupa koefisien kesamaan fenotipik dan dendogram yang menunjukkan pengelompokan dan jarak kesamaan berdasarkan karakter fenotipik yang dimiliki oleh seluruh aksesi yang diteliti. Koefisien kesamaan dihitung dengan rumus SMC (simple matching cocf) (Rholf, 1998) sebagai berikut:

$$
\mathrm{SMC}=\frac{a+d}{a+b+c+d}
$$

Keterangan:

$\mathrm{a}=$ jika ciri/karakter muncul pada kedua OTU (Operational Taxonomy Unit)

$\mathrm{d}=$ jika ciri/karakter tidak muncul pada kedua OTU

$\mathrm{b}=$ jika ciri/karakter muncul pada kedua OTU 1 dan tidak muncul pada OTU 2

$\mathrm{c}=$ jika ciri/karakter tidak muncul pada kedua OTU 1 tapi muncul pada OTU 2

Pengelompokan dilakukan dengan menggunakan metode UPGMA (Unweighted Pair Group Method with Arithmetic.

\section{HASIL DAN PEMBAHASAN}

Hasil pengamatan karakter fenotipik yang dilakukan pada jagung pulut hibrida hasil persilangan puncak menyatakan adanya variasi karakteristik fenotipik, mulai dari karakter pada warna anthosianin, bentuk hingga pola yang terdapat pada jagung pulut hibrida hasil persilangan puncak.

\section{Karakteristik Galur Jagung Pulut Hibrida}

Hasil penelitian yang telah dilakukan pada pendataan pada 17 galur tersebut, didapatkan karakter yang bervariasi disetiap galurnya berdasarkan buku Panduan Pelaksanaan Uji Kebaruan, Keunikan, Keseragaman, dan Kestabilan yang diterbitkan oleh Kementrian Pertanian Republik Indonesia Pusat Perlindungan Varietas Tanaman.

Beberapa karakter yang menunjukkan adanya variasi ditunjukkan pada gambar sebagai berikut :

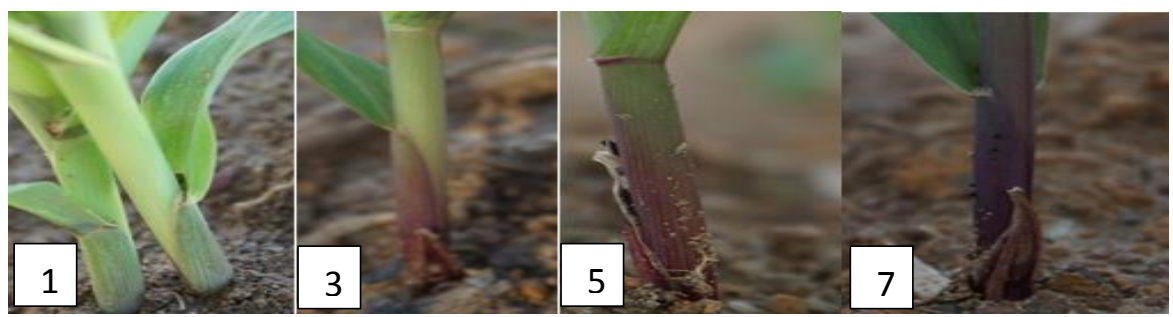

Gambar 1. Warna Antosianin (Daun Pertama). (1). Tidak ada atau sangat lemah; (3) Lemah; (5) Sedang; (7) Kuat 


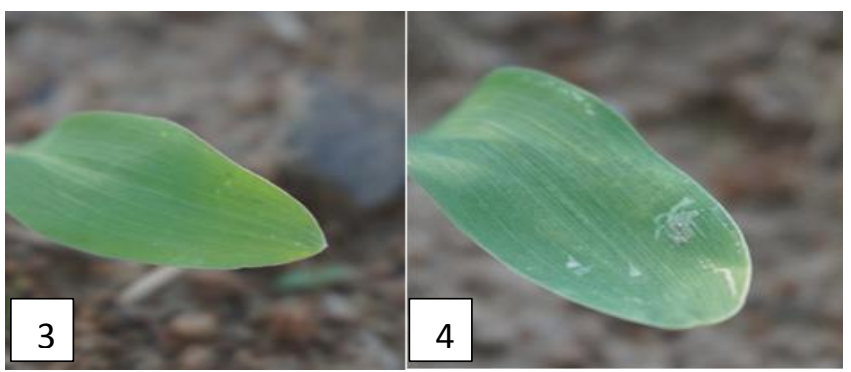

Gambar 2. Bentuk Ujung Daun (Daun Pertama). (3) Bulat; (4) Bulat agak tumpul

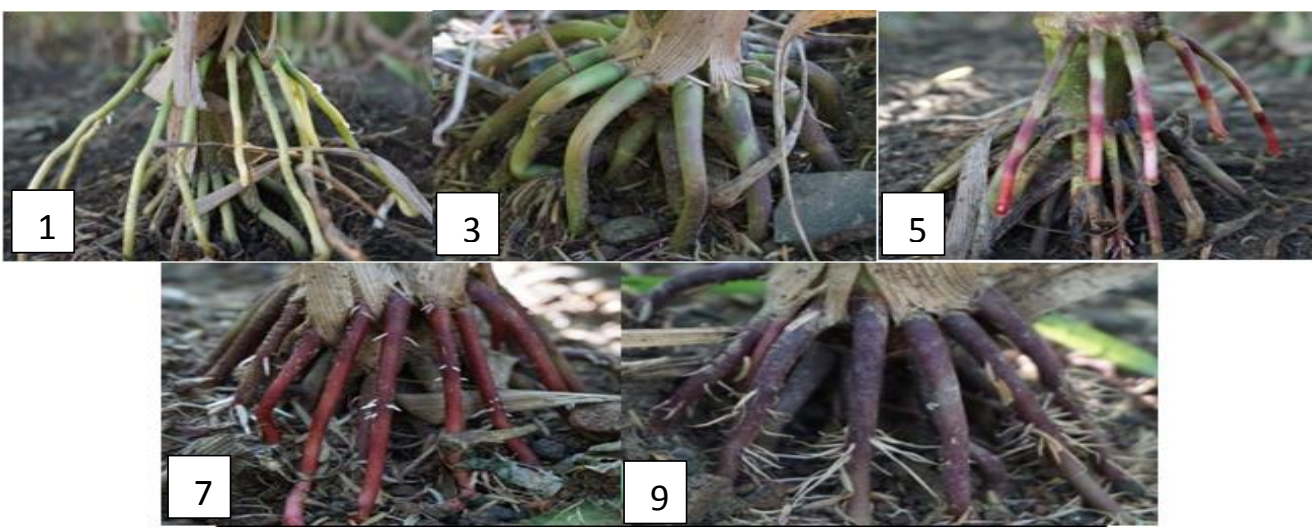

Gambar 3. Warna Antosianin pada Daun Akar Tunjang. (1). Tidak ada atau sangat lemah; (3) Lemah; (5) Sedang; (7) Kuat
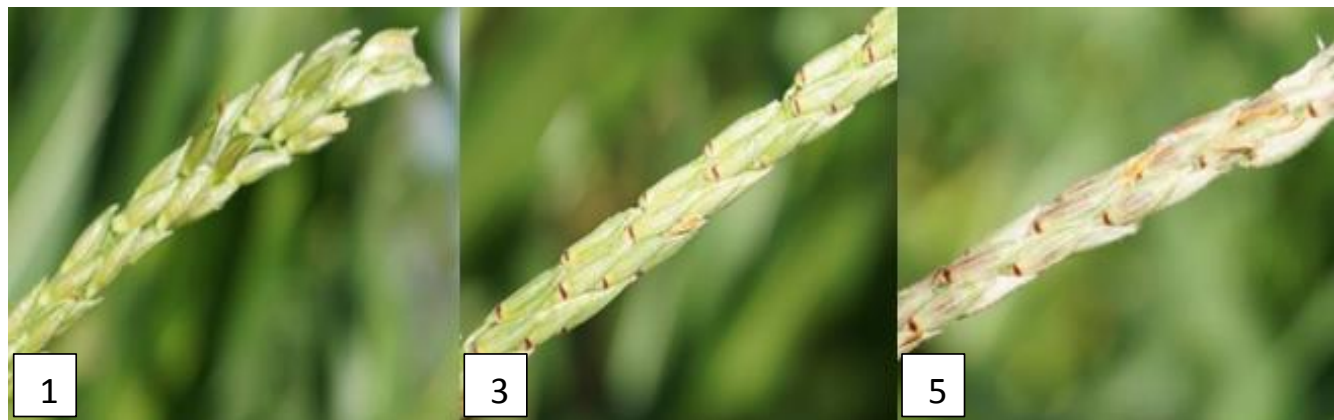

Gambar 4. Warna Antosianin pada Dasar Kelopak. (1). Tidak ada atau sangat lemah; (3) Lemah; (5) Sedang

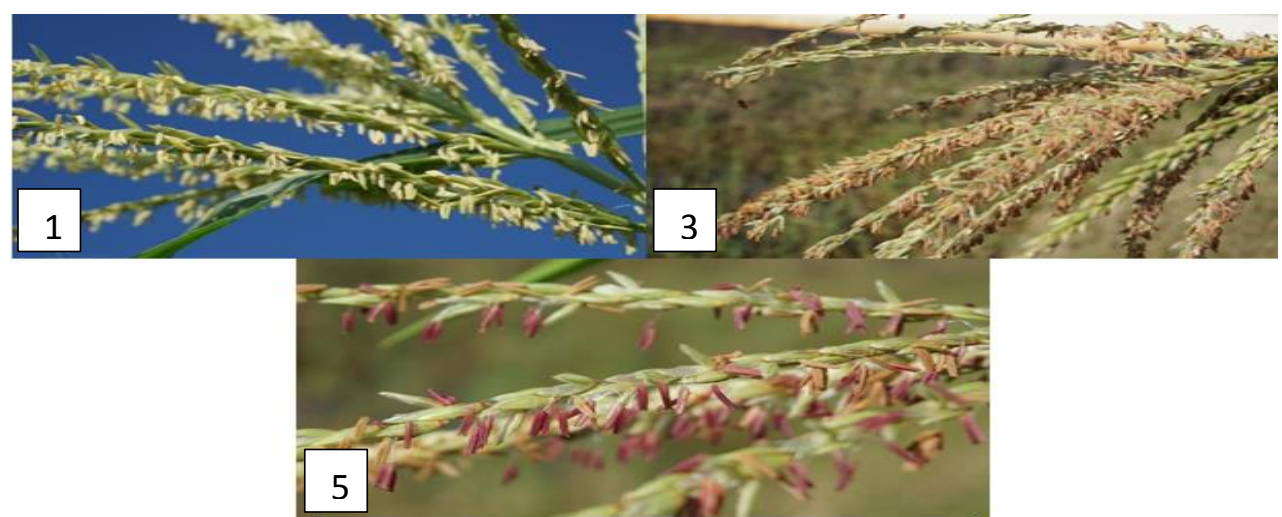

Gambar 5. Warna Antosianin pada Kepala Sari yang masih segar. (1). Tidak ada atau sangat lemah; (3) Lemah; (5) Sedang 


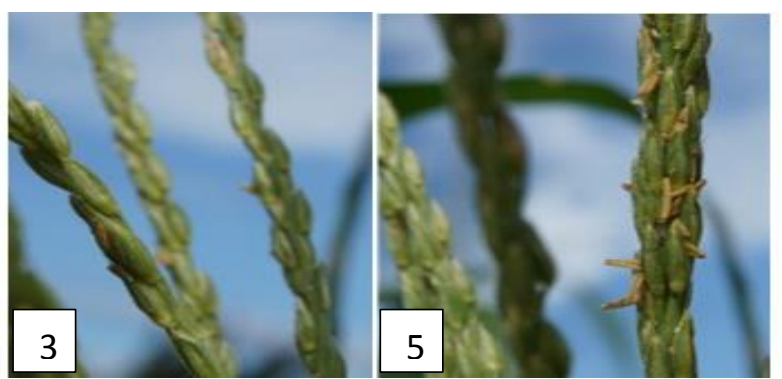

Gambar 6. Kerapatan Bulir. (3). Jarang; (5) Sedang

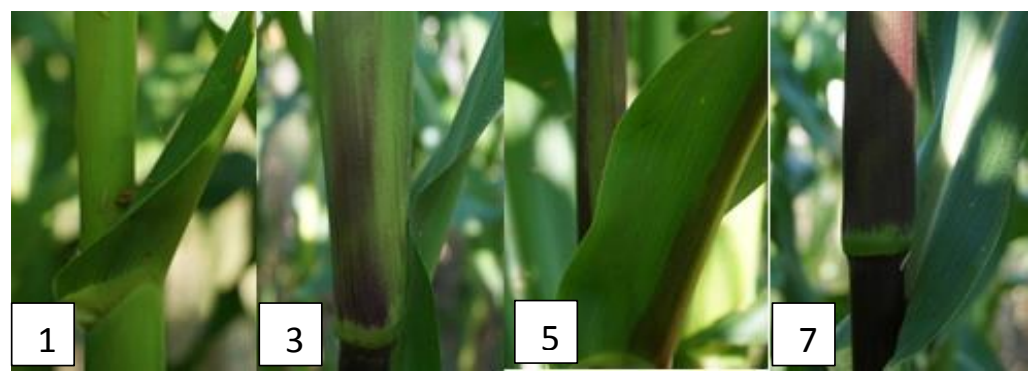

Gambar 7. Warna Antosianin pada Pertengahan Tinggi Tanaman. (1). Tidak ada atau sangat lemah; (3) Lemah; (5) Sedang; (7) Kuat

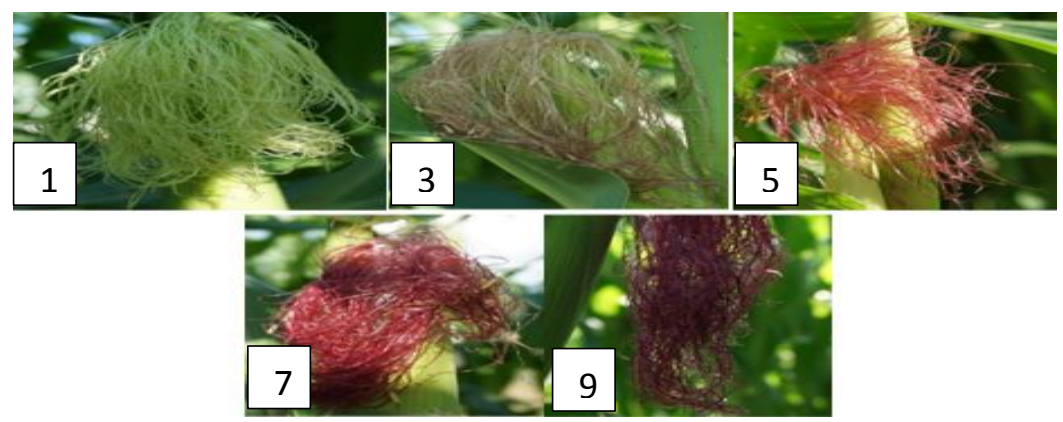

Gambar 8. Warna Antosianin pada Rambut. (1). Tidak ada atau sangat lemah; (3) Lemah; (5) Sedang; (7) Kuat; (9) Sangat Kuat

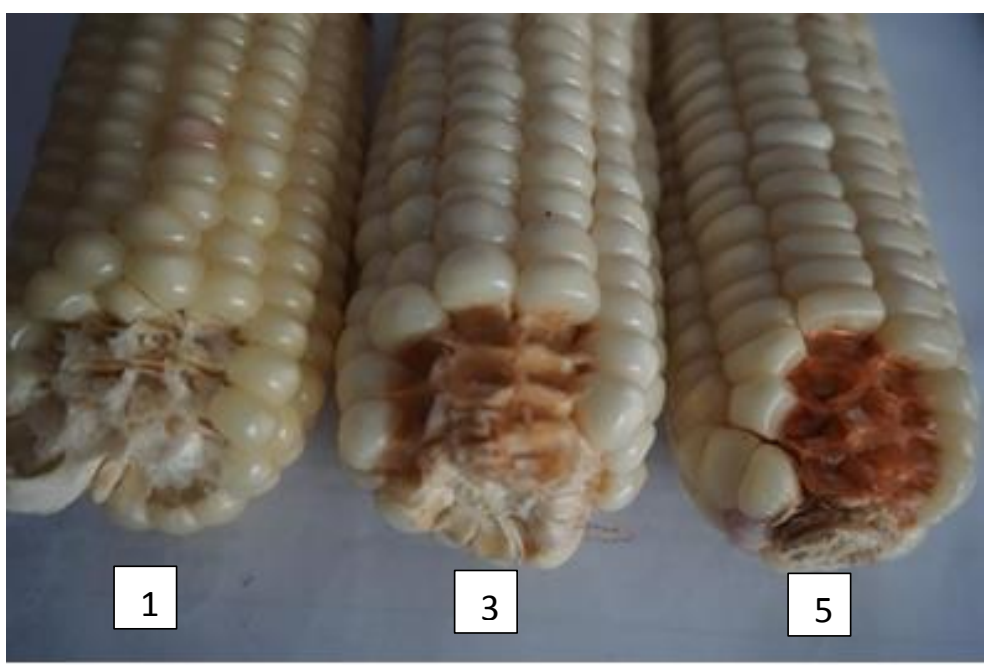

Gambar 9. Warna dan Intensitas Warna Antosianin pada Kelopak Janggel. (1). Tidak ada atau sangat lemah; (3) Lemah; (5) Sedang 


\section{Karakter fenotipik dan Pengelompokan Galur Jagung Pulut Hibrida}

Pengamatan data fenotipik yang dilakukan pada saat fase perkembangan sampai reproduksi 17 galur jagung pulut hibrida yang diteliti dengan mengamati 104 total karakter yang berasal dari 31 karakter (kualitatif dan kuantitatif). Berdasarkan ada dan tidaknya karakter yang dimiliki oleh jagung pulut hibrida dilakukan skoring pada data menggunakan kode 1 (jika karakter muncul) dan 0 (jika karakter tidak muncul), maka diperoleh data biner. Data biner kemudian diolah dengan menggunakan program (Numerical Taxonomy System) NTSYS, sehingga diperoleh hasil berupa matriks kesamaan fenotipik yang dapat dilihat pada Tabel2 sebagai berikut:

Tabel 2. Koefisien Kesamaan Fenotipik 17 galur jagung pulut hibrida

\begin{tabular}{|c|c|c|c|c|c|c|c|c|c|c|c|c|c|c|c|c|c|}
\hline & URI1 & $\begin{array}{c}\text { G8 } \\
\text { G1 }\end{array}$ & $\begin{array}{c}\text { G10 } \\
\text { G4 }\end{array}$ & $\begin{array}{c}\text { G8 } \\
\text { G7 }\end{array}$ & $\begin{array}{c}\text { G8 } \\
\text { G5 }\end{array}$ & $\begin{array}{c}\text { G8 } \\
\text { G3 }\end{array}$ & $\begin{array}{c}\text { G10 } \\
\text { G6 }\end{array}$ & $\begin{array}{c}\text { G10 } \\
\text { G1 }\end{array}$ & $\begin{array}{c}\text { G8 } \\
\text { G4 }\end{array}$ & $\begin{array}{c}\text { SOP } \\
\text { G }\end{array}$ & $\begin{array}{c}\text { G10 } \\
\text { G3 }\end{array}$ & $\begin{array}{c}\text { G10 } \\
\text { G5 }\end{array}$ & $\begin{array}{c}\text { G8 } \\
\text { G6 }\end{array}$ & $\begin{array}{c}\text { G10 } \\
\text { G7 }\end{array}$ & $\begin{array}{c}\text { G8 } \\
\text { G2 }\end{array}$ & $\begin{array}{c}\text { G10 } \\
\text { G2 }\end{array}$ & $\begin{array}{c}\text { PRM } \\
\text { T }\end{array}$ \\
\hline URI1 & 1 & & & & & & & & & & & & & & & & \\
\hline G8G1 & 0.77 & 1 & & & & & & & & & & & & & & & \\
\hline G10G4 & 0.75 & 0.75 & 1 & & & & & & & & & & & & & & \\
\hline G8G7 & $\mathbf{0 . 8 8}$ & 0.79 & 0.79 & 1 & & & & & & & & & & & & & \\
\hline G8G5 & 0.8 & 0.86 & 0.8 & 0.78 & 1 & & & & & & & & & & & & \\
\hline G8G3 & 0.72 & 0.8 & 0.76 & 0.76 & 0.81 & 1 & & & & & & & & & & & \\
\hline G10G6 & 0.77 & 0.75 & 0.79 & 0.77 & 0.8 & 0.8 & 1 & & & & & & & & & & \\
\hline G10G1 & 0.65 & 0.77 & 0.79 & 0.73 & 0.74 & 0.86 & 0.79 & 1 & & & & & & & & & \\
\hline G8G4 & 0.75 & 0.83 & 0.75 & 0.75 & $\mathbf{0 . 8 8}$ & 0.8 & 0.75 & 0.73 & 1 & & & & & & & & \\
\hline SOPG & $\mathbf{0 . 6}$ & 0.69 & 0.75 & 0.62 & 0.7 & 0.72 & 0.73 & 0.73 & 0.69 & 1 & & & & & & & \\
\hline G10G3 & 0.69 & 0.77 & 0.83 & 0.71 & 0.78 & 0.84 & 0.75 & 0.81 & 0.77 & 0.83 & 1 & & & & & & \\
\hline G10G5 & 0.76 & 0.74 & 0.82 & 0.78 & 0.81 & 0.79 & 0.84 & 0.76 & 0.76 & 0.76 & 0.82 & 1 & & & & & \\
\hline G8G6 & $\mathbf{0 . 8 8}$ & 0.82 & 0.78 & $\mathbf{0 . 8 8}$ & 0.83 & 0.77 & 0.76 & 0.7 & 0.78 & 0.68 & 0.76 & 0.79 & 1 & & & & \\
\hline G10G7 & 0.85 & 0.79 & 0.77 & 0.81 & 0.86 & 0.8 & 0.83 & 0.73 & 0.83 & 0.73 & 0.79 & 0.86 & $\mathbf{0 . 8 8}$ & 1 & & & \\
\hline G8G2 & 0.84 & 0.86 & 0.78 & 0.8 & $\mathbf{0 . 8 8}$ & 0.83 & 0.74 & 0.74 & 0.82 & 0.68 & 0.76 & 0.79 & 0.87 & 0.84 & 1 & & \\
\hline G10G2 & 0.67 & 0.71 & 0.77 & 0.73 & 0.76 & 0.82 & 0.75 & 0.87 & 0.73 & 0.75 & 0.79 & 0.82 & 0.72 & 0.77 & 0.74 & 1 & \\
\hline PRMT & 0.72 & 0.8 & 0.72 & 0.76 & 0.81 & 0.79 & 0.74 & 0.76 & 0.8 & 0.72 & 0.78 & 0.77 & 0.77 & 0.76 & 0.77 & 0.74 & 1 \\
\hline
\end{tabular}

Tabel 2 menunjukkan bahwa nilai kesamaan fenotipik 17 galur jagung pulut hibrida tersebut yang ditunjukkan pada matriks adalah jagung pulut Soppeng dan URI 1 memiliki nilai kesamaan fenotipik terkecil yaitu 0,60 dan nilai kesamaan fenotipik terbesar 0,88 dimiliki oleh 6 pasang jagung pulut hibrida yaitu G8G7 dan URI 1, G8G4 dan G8G5, G8G6 dan URI 1, G8G6 dan G8G7, G10G7 dan G8G6, G8G2 dan G8G5. Berdasarkan matriks koefisien kesamaan fenotipik dibuat pula pengelompokan berdasarkan kesamaan yang dimiliki dengan menggunakan metode UPGMA yang hasilnya disajikan berupa dendogram yang tertera pada Gambar 10 sebagai berikut: 


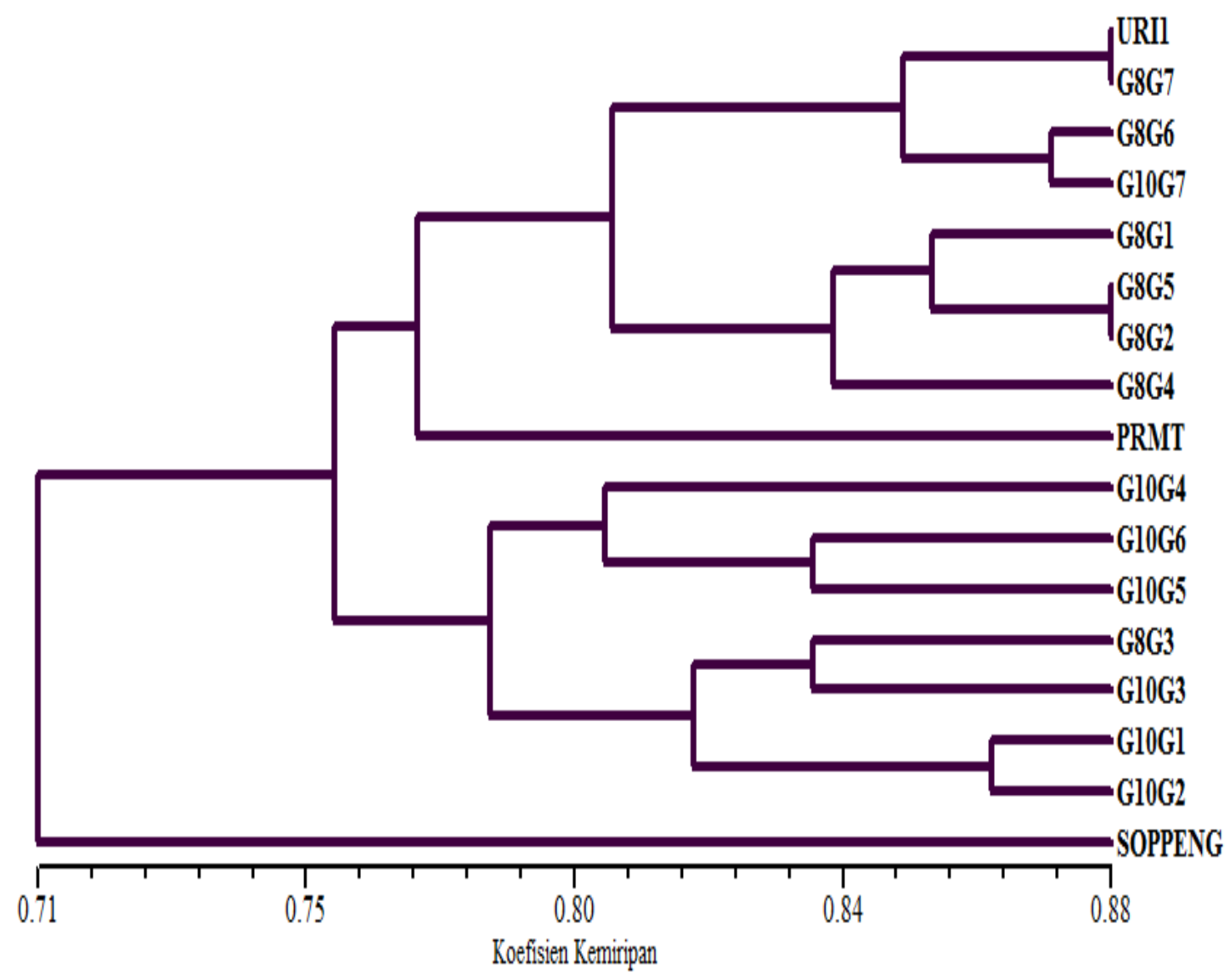

Gambar 10. Dendrogram Pengelompokan Berdasarkan Koefisien Kesamaan Fenotipik 17 Galur Jagung Pulut Hibrida Hasil Persilangan Puncak

Identifikasi karakterisasi jagung pulut memiliki keragaman fenotipik yang bervariasi. Hasil dendogram 17 galur jagung pulut hibrida pada Gambar 10, menunjukkan bahwa derajat pengelompokan berdasarkan kesamaan berkisar antara 0,71-0,88. Pada derajat kesamaan sekitar 0,77 maka 17 galur jagung pulut hibrida tersebut membentuk 3 kelompok yaitu kelompok 1 terdiri dari 9 entri, kelompok 2 terdiri dari 7 entri dan kelompok 3 hanya 1 entri yaitu jagung pulut Soppeng.

Sembilan entri pada kelompok 1 yaitu URI 1, 6 entri berasal dari hasil persilangan dengan URI 1 yaitu G8G7, G8G6, G8G1, G8G5, G8G2, dan G8G4, serta dua lainnya yaitu G10G7 dan Paramitha. Kelompok 2 terdiri dari 7 entri yaitu 6 diantaranya berasal dari hasil persilangan dengan pulut Soppeng (G10) yaitu G10G4, G10G6, G10G5, G10G3, G10G1, G10G2, dan satu lainnya yaitu G8G3.

Kelompok 3 merupakan kelompok yang hanya memiliki satu anggota yaitu Pulut Soppeng membentuk kelompok tersendiri dengan koefisien kesamaan yang dimiliki dengan entri lainnya hanya 0,71. Pulut Soppeng memiliki ketidaksamaan sekitar 0,29 dengan entri lainnya. Hal ini dikarenakan keseluruhan morfologi dari jagung pulut Soppeng memiliki ciri khas tersendiri dibanding jagung pulut lainnya baik dari segi batang, daun serta buah memiliki ukuran yang lebih kecil dibanding jagung pulut lainnya dan pulut Soppeng juga merupakan hasil persilangan dengan pulut Soppeng sehingga tidak ada perpaduan gen lain pada jagung pulut Soppeng. Menurut Juhriah dkk (2012) jagung Lokal Narang Tana Toraja memiliki kemiripan dengan lokal SulSel dari Soppeng dimana membentuk kelompok tersendiri 
karena secara morfologi berbeda dengan entri lainnya. Ukuran tinggi tanaman, panjang tongkol, jumlah biji perbaris, jumlah baris biji/tongkol dll lebih sedikit/ kecil dibanding entri lain. Perbedaan tersebut disebabkan adanya perbedaan umur. Perbedaan usia tersebut menyebabkan tanaman lain sudah membentuk naungan dan menjadi faktor penghambat pertumbuhan entri tersebut (selisih umur 20 hari). Koefisien keragaman genetik yang besar menunjukkan bahwa manipulasi genetik yang dilakukan akan memiliki peluang yang besar, sedangkan koefisien keragaman genetik kecil akan memberi peluang keberhasilan yang sangat kecil bila sifat tersebut diperbaiki (Ronald et al. 1999).

Hasil dendogram juga menunjukkan bahwa secara fenotipik URI 1 dan G8G7 demikian juga G8G5 dan G8G2 memiliki koefisien kemiripan fenotipik tertinggi yaitu 0,88. Pasangan jagung pulut hibrida URI 1 dan G8G7 memiliki kesamaan pada 21 ciri dari 31 ciri atau 92 dari 104 sifat ciri yang dianalisis. Sedangkan pasangan jagung pulut hibrida G8G5 dan G8G2 memiliki kesamaan pada 20 ciri dari 31 ciri atau 92 dari 104 sifat ciri yang dianalisis. Menurut Maemunah dan Yusran (2010), kecilnya perbedaan yang di timbulkan menunjukkan bahwa secara morfologi terdapat banyak kesamaan tanaman meskipun berasal dari galur yang berbeda. Perbedaan URI 1 dan G8G7 terletak pada Daun (Pola helai daun), Akar (pewarna antosianin pada akar tunjang), Batang (Warna Antosianin), Malai (sudut diantara poros utama dan cabang samping), Malai (letak percabangan samping), Malai (jumlah cabang samping utama), Malai (panjang poros utama di atas cabang bagian lebih atas), Tongkol (warna antosianin pada rambut), Tongkol (Panjang tongkol) dan Biji (Tipe biji). Sedangkan perbedaan G8G5 dan G8G2 terletak pada Daun Pertama (Warna Antosianin Pada Pelepah Daun), Daun (Sudut diantara helai dan batang), Akar (pewarna antosianin pada akar tunjang), Batang (Warna Antosianin), Malai (warna antosianin pada dasar kelopak), Malai (sudut diantara poros utama dan cabang samping), Malai (letak percabangan samping), Malai (panjang cabang samping), Malai (warna antosianin pada malai), Tongkol (Umur Munculnya Rambut), dan Tongkol (Panjang tangkai).

\section{KESIMPULAN}

1. Sembilan diantara 17 galur jagung pulut hibrida hasil Persilangan Puncak memiliki karakter dominan yang berbeda pada fenotipiknya yakni galur G8G1 warna anthosinin pada pelepah daunnya sedang; umur anthesisnya genjah hingga sedang (44,1-47 hst); dan sudut diantara poros utama dan cabang sampingnya kecil $\left(5-25^{\circ}\right)$, galur G8G5 memiliki jumlah cabang samping utama sedang (9-12 cabang), galur Soppeng memiliki warna anthosinin pada pelepah daunnya sedang; lebar helai daunnya sempit $(5-7 \mathrm{~cm})$; pola helai daunnya bengkok sedang; pewarnaan antosianin pada akar tunjangnya kuat; tinggi tanamannya sedang $(150,1-200 \mathrm{~cm})$; panjang tangkai tongkolnya sedang (10-15 cm); warna utama permukaan bijinya putih, galur G10G1 dan G10G3 memiliki tongkol yang panjang $(15-20 \mathrm{~cm})$, galur G10G4 memiliki panjang tangkai tongkol sedang (10-15 $\mathrm{cm}$ ) dan warna utama permukaan bijinya putih, galur G10G5 memiliki pewarnaan antosianin pada akar tunjang yang sedang dan terdapat anthosianin pada kelopak janggel seperti halnya G10G7, galur G10G6 dan G10G7 memilki intensitas warna anthosianin pada rambut sangat kuat. 8 lainnya memiliki ciri yang hampir sama. Galur Soppeng merupakan galur yang paling banyak terdapat karakter dominan yang berbeda.

2. Terdapat 6 pasang entri pada matriks yang memiliki matriks koefisien kesamaan fenotipik yang tinggi mencapai 0,88 (88\%), URI 1 dengan G8G7; URI 1 dengan G8G6; G8G7 dengan G8G6; 
G8G5 dengan G8G4; G8G5 dengan G8G2; dan G8G6 dengan G10G7, dan yang terendah 0,60 (60\%), Soppeng dengan URI 1. Pada derajat kesamaan 0,76 pada dendogram membentuk 3 kelompok entri. Empat Belas karakter data kuantitatif yang dianalisis variansi (Anova) terdapat 10 karakter yang berbeda nyata.

\section{UCAPAN TERIMA KASIH}

Penulis menyampaikan terima kasih kepada Kepala Balai Penelitian Tanaman Sereal Maros beserta staf atas kerjasama, bantuan, izin penggunaan lahan penelitian dan penyediaan bahan serta alat untuk kelancaran penelitian ini.

\section{DAFTAR PUSTAKA}

Boik R.J.. 2004. Lecture Notes: Statistics 537 Classical Multivariate Analysis Spring 2004. Departement of Mathematical Sciences. Montana State University

Juhriah, Baharuddin, Y. Musa, dan M. B. Pabendon. 2012. Kekerabatan Plasma Nutfah Jagung Lokal Sulawesi Selatan dengan Jagung Asal Cimmyt Berdasarkan Karakter Morfologi. Jurnal Ilmu Alam dan Lingkungan 3(6): 1-9.

Kartasapoetra A.G., 1988. Jagung Zea Mays dalam Teknologi Budidaya Tanaman Pangan di daerah Tropik. Bina Aksara, Jakarta.

Maemunah dan Yusran. 2010. Karakterisasi Morfologi Jagung Ketan di Kecamatan Ampana Tete Kabupaten Tojo Una-una. Media Litbang Sulteng 3(2): 151-159.

Moentono, M.D. 2001. Pembentukan dan Produksi Benih Varietas Hibrida. Balai Penelitian Benih dan Tanaman Pangan Sukomandi.

Rholf, F.J. 1998. NTSYSpc, Numerical Taxonomy Analysis System Version 2.0. Exeter Software, New York.

Ronald, P.S., P.D. Brown, G.A. Penner, A. Brule, and S. Kibite, 1999. Heritability of Hull Percentage in Oat. Crop Sci 39: 2-57.

Subekti, N.A., Syafaruddin, R. Efendi dan S. Sunarti. 2008. Morfologi Tanaman dan Fase Pertumbuhan Jagung. http:// balitsereal.litbang.deptan.go.id/bja gung/empat. pdf (akses 5 November 2015)

Zubachtirodin, B. Sugiharto, Mulyono, dan D. Hermawan, 2011. Teknologi Budidaya Jagung. Direktorat Jenderal Tanaman Pangan. Jakarta. 